\title{
Evaluation of Properties from the Cutting Surface after Applying Laser Beam Technology Using Different Scales of Cutting Speed
}

Andrej Zrak, Jozef Meško, Augustín Sládek, Martin Vicen

Faculty of Mechanical Engineering, University of Žilina, Univerzitná 1, 01008 Žilina. Slovak Republic. E-mail: andrejzrak@gmail.com, jozef.mesko@fstroj.uniza.sk, augustin.sladek@fstroj.uniza.sk, martin.vicen@fstroj .uniza.sk

This article is focused on the processing of steel materials by thermal cutting technologies - laser cutting. It analyzes the impact of technological parameters - cutting speed effect on the cutting surface quality. The goal is to define the parameters ensuring proper amount of heat absorbed into the material that does not affect the cutting surface to avoid difficultiesduring further processing - such as drilling, thread cutting etc. To determinethe effect of cutting speed on the quality of the cutting surface, it was necessary to measure an internal stress and a hardness of HVM. Internal stresses in the experimental part of the article was measured by the $\mathrm{X}$-ray diffraction and the resulting values are shown in the graphs.In the article are also shown microstructures of selected samples after the laser cutting under the different cutting parameters.

Keywords: laser cutting, heat affected zone, properties of cutting surface, hardness of cutting surface

\section{Acknowledgement}

This contribution was made with the financial assistance of VEGA agency, project No. VEGA 1/0836/13 and KEGA$014 \check{Z} U-4 / 2016, K E G A-034 \check{Z} U-4 / 2015$.

\section{References}

[1] ZRAK, A. - KOŇÁR, R. - JANKEJECH, P. 2015. Influence of Chemical Composition in Steel on Laser Cutting Stability In: Manufacturing technology. Vol. 15, No. 4 (2015), pp. 748-752.

[2] KOŇÁR, R., MIČIAN, M., MEŠKO, J., SVENTEK, M. (2015). Identification of lack of fusion and penetration in circumferential fillet weld by phased array ultrasonic method in gas industry In: Communications : scientific letters of the University of Žilina. - ISSN 1335-4205. Vol. 17, No. 3 (2015), pp. 98-102.

[3] ASHBY M. F., EASTERLING K. E. (1984). The transformation hardening of steel surfaces by laser beams - I. In: Hypo-eutectoid steels. Acta Metall. Vol. 32, No 11, pp. 1935-1948.

[4] RADEK, N., ANTOSZEWSKI, B. (2009) Influence of laser treatment on the properties of electro-spark deposited coatings. In: Kovove Materialy - Metallic Materials 47, pp. 31-38, 2009

[5] KOŇÁR, R., MIČIAN, M. (2014). Non-destructive testing of welds in gas pipelines repairs with Phased Array ultrasonic technique. In: Manufacturing technology, Vol. 14, No. 1, pp. 42-47.

[6] DOPJERA, D., KOŇÁR, R., MIČIAN, M. (2014) Ultrasonic testing of girth welded joint with TOFD and Phased Array. In: Manufacturing technology, Vol. 14, No. 3, pp. 281-286.

[7] DOMAGALA, A., TOFIL, S. (2011) The comparison between different types of cutting - selection of the best method. In: 9th European Conference of Young Research and Scientific Workers, Transcom 2011, 27-29 June 2011, Słowacja.

[8] MIČIETOVÁ, M., NESLUŠAN, M., ČILLÍKOVÁ, M. (2013). Influence of surface geometry and structure after non-conventional methods of parting on the following milling operations. In: Manufacturing technology, Vol. 13, No. 2, pp. 152-157.

[9] PODPROCKÁ, R., BOLIBRUCHOVÁ, D., MALIK, J. (2015) Defects in high pressure die casting process In: Manufacturing technology. Vol. 15, No. 4, pp. 674-678.

[10] RADEK, N., MEŠKO, J., ZRAK A. (2014). Technology of Laser Forming. In: Manufacturing Technology Vol. 14, No. 3, pp. 428-431. 